\title{
Association of HPV and EBV in Oral Verrucous Squamous Cell Carcinoma and Oral Verrucous Hyperplasia
}

\author{
Eakapong Tamboon ${ }^{1}$ Phetmany Sihavong ${ }^{2,3}$ Nakarin Kitkumthorn ${ }^{1}$ Dusit Bumalee ${ }^{3}$ \\ Tawepong Arayapisit ${ }^{4}$ Puangwan Lapthanasupkul ${ }^{3}$
}

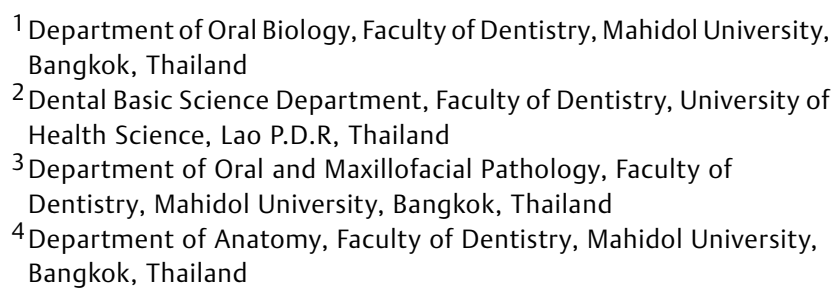

Address for correspondence Puangwan Lapthanasupkul, DDS, MSc, PhD, Department of Oral and Maxillofacial Pathology, Faculty of Dentistry, Mahidol University, 6 Yothi Street, Bangkok 10400, Thailand (e-mail: puangwan.lap@mahidol.ac.th).

Eur J Dent 2022;16:367-372.
Abstract
Keywords
- oral verrucous squamous cell carcinoma
- oral verrucous carcinoma
- oral verrucous hyperplasia
- HPV
- EBV

Objective Oral verrucous squamous cell carcinoma or oral verrucous carcinoma (OVC) is a rare verrucous variant of oral squamous cell carcinoma (OSCC), which accounts for 2 to $12 \%$ of all oral carcinomas. Oral verrucous hyperplasia $(\mathrm{OVH})$ is clinically similar to OVC and has been proposed to be a precursor lesion of OVC. Etiopathogenesis of both lesions is still inconspicuous. Oncogenic viruses such as human papillomavirus (HPV) and Epstein-Barr virus (EBV) have been reported to be associated with some cases of OSCC, and we hypothesized that it may act as a causative agent of these verrucous lesions. This study aimed to investigate frequency of HPV and EBV infections in OVC and OVH.

Material and Methods Using polymerase chain reaction (PCR), a total of 35 formalinfixed paraffin-embedded (FFPE) tissue samples, including 27 OVC samples and $8 \mathrm{OVH}$ samples, were investigated for HPV and EBV infection. HeLa and B95-8 cell lines were used as positive controls of HPV and EBV PCR, respectively.

Results All OVC and OVH samples show a positivity to GAPDH, whereas neither HPV nor EBV PCR products was detected in both OVC and OVH samples.

Conclusions In summary, our study demonstrated that HPV and EBV are not involved in pathogenesis of OVC and OVH. Other etiologic factors contributing to OVC and $\mathrm{OVH}$ need to be further clarified.

\section{Introduction}

Oral verrucous squamous cell carcinoma or oral verrucous carcinoma (OVC), a low-grade variant of oral squamous cell carcinoma (OSCC), accounted for approximately 2 to $12 \%$ of all oral carcinomas, with approximately $80 \% 5$-year survival rate. ${ }^{1,2}$ Etiological factors of OVC are not clarified but may be related with smoking, areca nut chewing, alcohol, and oral
DOI https://doi.org/ 10.1055/s-0041-1735907. ISSN 1305-7456. (c) 2021. The Author(s).

This is an open access article published by Thieme under the terms of the Creative Commons Attribution License, permitting unrestricted use, distribution, and reproduction so long as the original work is properly cited. (https://creativecommons.org/licenses/by/4.0/)

Thieme Medical and Scientific Publishers Pvt. Ltd., A-12, 2nd Floor, Sector 2, Noida-201301 UP, India 
microorganisms. ${ }^{1,3}$ Furthermore, many studies have demonstrated human papillomavirus (HPV) infection in OVC. Noble-Topham et al showed that HPV infection was detected $(48 \%)$ in OVC by polymerase chain reaction (PCR), ${ }^{4}$ while Fujita et al found HPV infection in $48 \%$ of OVC using PCR and $26 \%$ of OVC using in situ hybridization (ISH). ${ }^{5}$ On the other hand, a few studies did not find HPV infection in OVC. ${ }^{6,7}$ These findings indicated that the role of HPV in OVC is inconclusive. Epstein-Barr virus (EBV) is another oncogenic virus that is known to be a cause of nasopharyngeal cancer and B-cell lymphoma. ${ }^{8}$ A previous study showed that epithelial cells transfected with the LMP1 (latent membrane protein 1) gene in the skin of transgenic mice were able to induce epithelial hyperplasias or neoplasias. This suggested that EBV may cause proliferation of oral squamous epithelium. ${ }^{9}$ Additionally, previous reports revealed that EBV might be related with OVC. ${ }^{10,11}$ To date, there is limited information regarding EBV infection in OVC.

OVC is defined by a slow-growing tumor, with a tendency of local invasion and rare recurrence. The clinical features of OVC appear as well-demarcated, painless, thick plaque with papillary or verruciform surface projections. This histopathologic feature may be mistaken for benign epithelial hyperplasia. Interestingly, the clinical and histopathological morphologies of OVC are closely similar to oral verrucous hyperplasia (OVH). Both OVC and OVH show similar clinical appearance, and the common oral sites of these lesions are also similar. ${ }^{12,13}$

In the present study, OVC and OVH specimens were examined for the presence of HPV and EBV infections by PCR. The result will support whether OVC and OVH are associated with HPV and EBV.

\section{Material and Methods}

\section{Ethic Approval and Sample Collection}

Ethical consideration of this study was approved by the Institutional Review Board of Faculty of the Dentistry/Faculty of Pharmacy, Mahidol University (COE. No.MU-DT/PY-IRB 2018/060.1312 and 2021/014.0402). Archival pathological specimens of the Department of Oral and Maxillofacial Pathology, Faculty of Dentistry, Mahidol University were assessed, and a total of 35 samples, including 27 cases of OVC and 8 cases of $\mathrm{OVH}$, were retrieved. The clinicopathological information of each case, including age, sex, and tumor location, was collected from pathology requested forms. Histopathological slides of these cases were confirmed by two oral pathologists (P.S. and P.L.). Histopathological diagnosis of $\mathrm{OVH}$ and OVC was made, based on criteria recommended by Lin et al. ${ }^{7}$ The criteria for a diagnosis of OVH include: 1) epithelial hyperplasia with hyperkeratosis and verruciform surface; 2 ) the lesional epithelium does not invade the subjacent connective tissue or is elevated compared to the normal adjacent epithelium. The criteria for histopathological diagnosis of OVC were as follows: 1) epithelial hyperplasia with hyperkeratosis, broad blunt rete ridges, and showing no or mild dysplasia; 2 ) the lesional epithelium pushes into the underlying connective tissue, compared with the normal adjacent epithelium. Histopathological photos of representative OVC and $\mathrm{OVH}$ samples were demonstrated in -Fig. $\mathbf{1}$.

The wax blocks of paraffin-embedded tissue of desired samples were sectioned to obtain tissue sections, approximately three to four ribbons with $10-\mu \mathrm{m}$ thickness, using a microtome (LEICA RM 2255). The tissue sections were placed into a sterile $1.5 \mathrm{~mL}$ microcentrifuge tube for tissue DNA extraction. Genomic DNA extraction was performed, according to the phenol-chloroform protocol previously proposed by Kasperbauer et al. ${ }^{14}$ The concentration of obtained DNA was measured using a NanoDrop 2000 spectrophotometer (ND-1000 Spectrophotometer, NanoDrop Technologies, Welmington, DE, USA). The optical density 260/280 ratio being greater than 1.8 is acceptable for DNA purity and PCR. PCR was performed on the extracted DNA using the following three primers: glyceraldehyde 3-phosphate dehydrogenase (GAPDH) was served as the internal control to test the quality of DNA. GP5 +/GP6+ primers encoding major capsid protein were examined to detect HPV infection. Finally, LMP1 primers encoding EBV latent membrane protein was used to detect EBV infection. The properties of these primers were shown in - Table 1. HeLa cell line (a cervical carcer cell line containing HPV18 DNA) and B95-8 cell line (EBV-producing marmoset B-cell line) were used as positive controls for HPV PCR and EBV PCR, respectively. Distilled water was used as a negative control. The total $10 \mu \mathrm{l}$ PCR reaction contained $1 \mathrm{x}$ PCR buffer (Thermo Scientific, Massachusetts USA), $25 \mathrm{mM}$

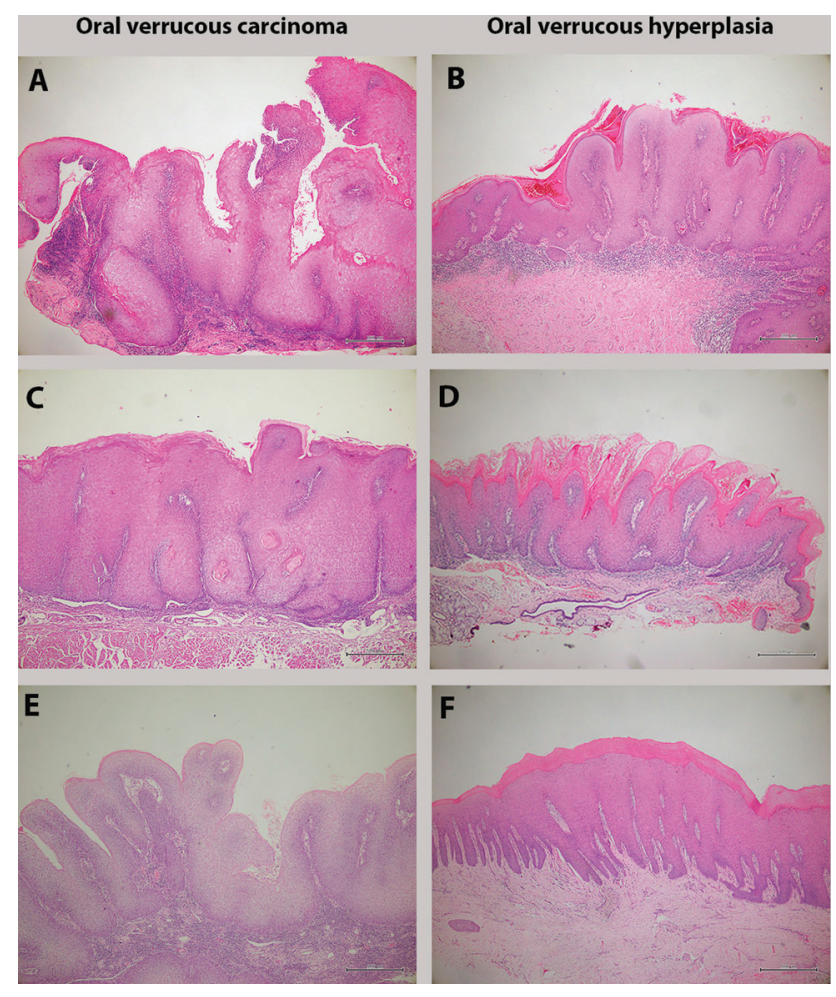

Fig. 1 Histopathologic features of oral verrucous squamous cell carcinoma (OVSCC) and oral verrucous hyperplasia (OVH). (A, C, E) oral verrucous carcinoma (OVC) showing papillary epithelial hyperplasia with bulbous rete ridges pushing into the connective tissue. (B, D, F) OVH showing epithelial proliferation with verrucous surface elevating from the adjacent normal epithelium. 
Table 1 Properties of oligonucleotide primer sequences and conditions for PCR analyses in this study

\begin{tabular}{|c|c|c|c|}
\hline Detection & Primer & Amplicon size (bp) & Sequence $5^{\prime}-3^{\prime}$ \\
\hline \multirow{2}{*}{$\begin{array}{l}\text { Internal control } \\
(G A P D H)\end{array}$} & GAPDH forward & \multirow[t]{2}{*}{150} & CAGCCGCATCTTCTTTTG \\
\hline & GAPDH reverse & & CAACAATATCCACTTTAC \\
\hline \multirow[t]{2}{*}{ EBV DNA } & LMP1 forward & \multirow[t]{2}{*}{129} & CCAGACAGCCAACAATTG \\
\hline & LMP1 reverse & & GGTAGAAGACCCCCTAC \\
\hline \multirow[t]{2}{*}{ HPV DNA } & GP5+ & \multirow[t]{2}{*}{150} & TTTGTTACTGTGGTAGATACTAC \\
\hline & GP6+ & & CTTATACTAAATGTCAAATAAAAAG \\
\hline
\end{tabular}

$\mathrm{MgCl}_{2}$ (Thermo Scientific, Massachusetts, USA), $200 \mathrm{mM}$ dNTPs (Thermo Scientific, Massachusetts, USA), $0.2 \mathrm{mM}$ primers, 0.5 U Taq DNA polymerase (Thermo Scientific, Massachusetts, USA), and $50 \mathrm{ng} / \mathrm{\mu l}$ of template DNA. All PCR reactions were done in the thermal cycler with the following conditions: 10 -minute initial denaturation at $95^{\circ} \mathrm{C}, 45$ cycles of denaturation at $95^{\circ} \mathrm{C}$ for 45 seconds, annealing at $55^{\circ} \mathrm{C}$ for 45 seconds, extension at $72{ }^{\circ} \mathrm{C}$ for 45 seconds, and a final extension at $72{ }^{\circ} \mathrm{C}$ for 10 minutes. Following amplification, the PCR products were separated by gel electrophoresis using $1 \%(\mathrm{w} / \mathrm{v})$ agarose gel in $1 \mathrm{x}$ TBE buffer, and then stained with RedSafe Nucleic Acid Staining Solution (Intron, Korea).

\section{Results}

A total of 35 histopathological samples consisting of 27 specimens of OVC and 8 specimens of OVH were obtained from the Department of Oral and Maxillofacial Pathology, Faculty of Dentistry, Mahidol University. The clinicopathological features of OVC patients were presented in - Table 2. The OVC cases consisted of 21 (77.8\%) females and 6 (22.2\%)

Table 2 Clinical information of OVC and OVH cases

\begin{tabular}{|l|l|l|}
\hline Characteristics & OVC $(\boldsymbol{n}=\mathbf{2 7})$ & OVH (n=8) \\
\hline $\begin{array}{l}\text { Age, mean } \\
\text { (range) years }\end{array}$ & $75.44(51-103)$ & $70.5(59-84)$ \\
\hline Sex & $21(77.8 \%)$ & $6(75 \%)$ \\
\hline Female & $6(22.2 \%)$ & $2(25 \%)$ \\
\hline Male & $5(18.5 \%)$ & $4(50 \%)$ \\
\hline Location & $8(29.6 \%)$ & $4(50 \%)$ \\
\hline $\begin{array}{l}\text { Gingiva/alveolar } \\
\text { mucosa }\end{array}$ & $3(11.1 \%)$ & 0 \\
\hline Buccal mucosa & $5(18.5 \%)$ & 0 \\
\hline Lip & $3(11.1 \%)$ & 0 \\
\hline Tongue & $3^{\text {a }(11.1 \%)}$ & 0 \\
\hline Palate & & \\
\hline Multiple sites &
\end{tabular}

Abbreviations: OVC, oral verrucous carcinoma; OVH, oral verrucous hyperplasia.

${ }^{\mathrm{a}}$ Two cases were located at the lip and buccal mucosa and the other case was found at the gingiva and buccal mucosa. males, with a 3.5:1 female to male ratio, and the mean age of 75.44 years (ranged from 51-103 years). The most common site of the OVC was the buccal mucosa (29.6\%), followed by the tongue (18.52\%). OVH cases were composed of 6 (75\%) females and $2(25 \%)$ males, with a 3:1 female to male ratio, and the mean age of 70.5 years (ranged from 59-84 years). The most common sites of OVH cases were the gingiva (50\%) and the buccal mucosa (50\%).

The DNA fragments of human GAPDH were successfully amplified in all samples of OVC and OVH in our study. In addition, internal control amplifications were also negative. Our study found that all 35 samples (100\%) of OVC and OVH were negative for both HPV and EBV infections. Representatives of the PCR amplification for each gene fragments were shown in - Fig. 2.

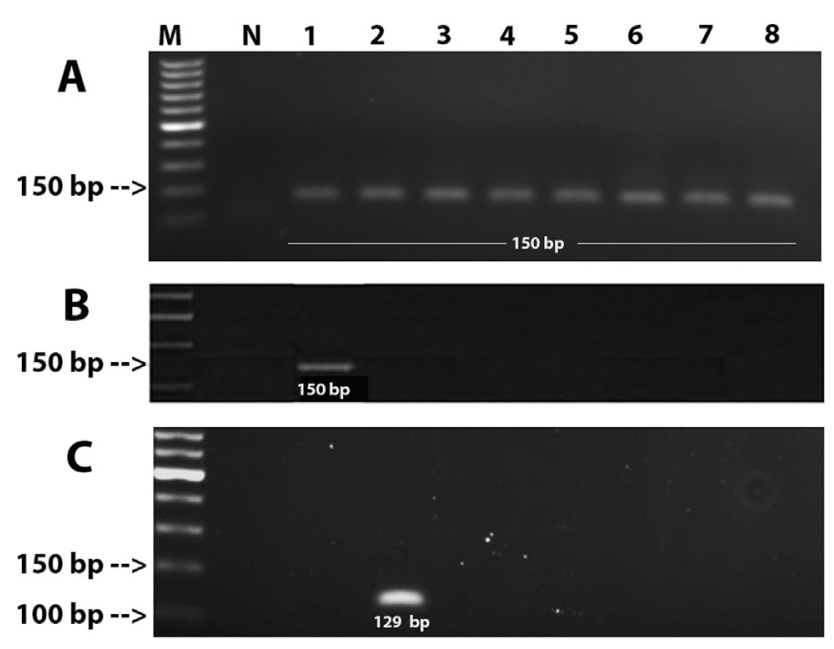

Fig. 2 The $1 \%(w / v)$ agarose gel electrophoresis of polymerase chain reaction (PCR) products. Lane M: 100 bp ladder; Lane N: negative control; Lane 1 = positive control for human papillomavirus (HPV) (HeLa cell); Lane 2 =positive control for Epstein-Barr virus (EBV) (B958 cell); Lane 3-5 = oral verrucous carcinoma (OVC) samples; Lane 6$8=$ oral verrucous hyperplasia (OVH) samples. (A): Representative gel pictures showing polymerase chain reaction ( $P C R$ ) products positive for GAPDH (150 bp) in all samples of OVC and OVH. (B): Representative gel pictures showing PCR products negative for HPV, only positive control showed amplification (150 bp). (C): Representative gel pictures showing PCR products negative for EBV, only positive control showed amplification (129bp). 


\section{Discussion}

Our results demonstrating an absence of HPV and EBV DNA in OVC and OVH is surprising and contradicts our hypothesis that these viral infections would take a role in the promotion of epithelial verrucous proliferation is some OVC or $\mathrm{OVH}$ cases. Regarding the previous studies ( - Table $\mathbf{3}$ ), the role of HPV in these oral verrucous lesions has been inconclusive. For $\mathrm{OVH}$, only a very few studies investigating HPV in $\mathrm{OVH}$ and questionable results were found. For instance, Shroyer and Greer showed HPV DNA detected in $28.5 \%$ of $\mathrm{OVH}^{15}$ whereas no HPV DNA was found in OVH from the studies conducted by del Pino et al. ${ }^{16}$ In addition, Lin et al found very low expression of HPV 16/18 E6 protein (0.3\% mean labeling index) in $30 \mathrm{OVH}$ samples. ${ }^{7}$ Our results further support that HPV may have no role in the development of $\mathrm{OVH}$.

HPV detection in OVC is also highly controversial. One previous study demonstrated that HPV DNA was detected in all lip verrucous carcinoma (100\%), using PCR with sequence analysis and restriction fragment length polymorphism analysis. However, only five samples were investigated in their study. ${ }^{17}$ Several studies from USA, UK, Iran, Canada, and Japan have shown considerably high prevalence of HPV infection (14.28-48\%) in OVC. These studies conducted a considerably large cohort of OVC, ranging from 7 to 25 OVC samples. ${ }^{4,5,18-20}$ On the other hand, other studies revealed no HPV infection in OVC. $6,7,15$ In Thailand, although a prior study reported that one (25\%) of a total four OVC cases showed coinfection of HPV$16 / 18,{ }^{21}$ our finding with a larger cohort of OVC (27 cases) suggests that HPV has no relation with OVCs in Thai patients. Taken together, these discrepant findings may be due to differences in ethnicity, and further study is required to elucidate. It is worth noting that the negative relationship between HPV and verrucous carcinoma has also been reported in verrucous carcinoma at the other sites, including vulva and penis. $^{22-24}$ Similar to OVC, both vulvar and penile verrucous carcinoma are predominantly found in elderly, and show the same clinical and histological features. ${ }^{24,25}$ These observations point out that a relationship between verrucous carcinoma and HPV may not be strong.

With regard to EBV infection, only a few studies investigated EBV in OVC, and very few cases were performed in those studies. ${ }^{11,26}$ To our knowledge, study of EBV infection in $\mathrm{OVH}$ is not found in the English literature. We observed no participation of EBV in 27 OVCs and 8 OVHs. The absence of EBV relation in OVC corresponded to a previous study, demonstrating no EBV DNA in 4 OVC cases using conventional PCR. ${ }^{26}$ Nevertheless, the other two studies found EBV

Table 3 Overview of previous studies investigating HPV in OVC and OVH

\begin{tabular}{|c|c|c|c|}
\hline Reference & $\begin{array}{l}\text { Number and } \\
\text { type of samples }\end{array}$ & Method of HPV detection (primer) & $\begin{array}{l}\text { Detected HPV types } \\
\text { (overall HPV prevalence in \%) }\end{array}$ \\
\hline Shroyer and Greer ${ }^{15}$ & $\begin{array}{l}-14 \text { OVH } \\
-3 \text { OVC } \\
\text { (FFPE) }\end{array}$ & $\begin{array}{l}\text { - ISH (31/33/35) } \\
\text { - PCR (specific primer for HPV-type 16) }\end{array}$ & $\begin{array}{l}\text { - } 16(28.5 \%) \text { by PCR in OVH } \\
\text { - } 16,31 / 33 / 35(28.5 \%) \text { by ISH in OVH } \\
\text { - No HPV infection in OVC was found. }\end{array}$ \\
\hline Noble-Topham et al ${ }^{4}$ & $\begin{array}{l}-25 \text { OVC } \\
\text { (FFPE) }\end{array}$ & - PCR (6b/11,16,18 primers) & $-6 / 11,11,16,18,16 / 18(48 \%)$ \\
\hline Shroyer and Greer ${ }^{18}$ & $\begin{array}{l}-17 \text { OVC } \\
\text { (FFPE) }\end{array}$ & $\begin{array}{l}\text { - PCR and DNA slot-blot hybridization } \\
\text { - ISH }\end{array}$ & $\begin{array}{l}-7 / 17(41 \%) \\
-6 / 11,6 / 18,31 / 33 / 35\end{array}$ \\
\hline Mitsuishi et al ${ }^{17}$ & -5 OVC & $\begin{array}{l}\text { - PCR, sequence analysis and } \\
\text { restriction fragment length } \\
\text { polymorphism }\end{array}$ & $-20(74.8 \%)$ \\
\hline Fujita et $a^{5}$ & - 23 OVC (FFPE) & $\begin{array}{l}\text { - PCR (SPF primer) } \\
\text { - ISH }(18,6,74,11,33)\end{array}$ & $\begin{array}{l}-18,6,74,11,33(48 \%) \text { by PCR } \\
-6,8 / 18,6 / 18 / 74(26 \%) \text { By ISH }\end{array}$ \\
\hline Saghravanian et al ${ }^{19}$ & - 21 OVC (FFPE) & - PCR (GP5/GP6) & $-16 / 18(14.3 \%)$ \\
\hline de Spindula-Filho ${ }^{6}$ & $\begin{array}{l}-8 \text { OVC } \\
\text { (FFPE) }\end{array}$ & - PCR (GP5/GP6) & - No HPV infection in OVC \\
\hline Lin et $\mathrm{al}^{7}$ & $\begin{array}{l}-48 \text { OVC } \\
-30 \text { OVH } \\
\text { (FFPE) }\end{array}$ & - IHC (16/18 E6 protein) & $\begin{array}{l}\text { - Very low labeling indices of } \\
\text { HPV } 16 / 18 \text { E6 protein in both OVC } \\
(0.5 \%) \text { and OVH }(0.3 \%)\end{array}$ \\
\hline del Pino et $a^{16}$ & $\begin{array}{l}-5 \text { OVC } \\
-1 \text { OVH } \\
\text { (FFPE) }\end{array}$ & - PCR (GP5/GP6) & $\begin{array}{l}\text { - Only } 1 \text { case }(20 \%) \text { in OVC } \\
\text { - No HPV infection in OVH }\end{array}$ \\
\hline Stokes et $\mathrm{al}^{20}$ & $\begin{array}{l}-7 \text { OVC } \\
\text { (FFPE) }\end{array}$ & $\begin{array}{l}\text { - PCR (GP5/GP6) } \\
\text { - ISH (1R6) }\end{array}$ & $\begin{array}{l}\text { - Only } 1 \text { case }(14.28 \%) \text { by PCR } \\
\text { - HPV-type } 16(14.28 \%) \text { by ISH }\end{array}$ \\
\hline Sritippho et al ${ }^{21}$ & $\begin{array}{l}-4 \text { OVC } \\
\text { (FFPE) }\end{array}$ & $\begin{array}{l}\text { - Real-time PCR (specific } \\
\text { primer for HPV-type } 16 \text { and } 18 \text { ) }\end{array}$ & $\begin{array}{l}\text { - Only } 1 \text { case }(25 \%) \\
\text { - Coinfection of HPV-16/18 }\end{array}$ \\
\hline
\end{tabular}

Abbreviations: FFPE, formalin-fixed paraffin-embedded; HPV, human papillomavirus; ISH, in situ hybridization; OVC, oral verrucous carcinoma; OVH, oral verrucous hyperplasia; PCR, polymerase chain reaction. 
infection in one case of OVC using PCR. ${ }^{10,11}$ EBV is a known cause of nasopharyngeal carcinoma and is also associated with several oral neoplasms including B-cell lymphomas and lymphoepithelial carcinoma. ${ }^{8}$ Several studies previously investigated the possible implication of EBV in OSCC, the common oral malignancy often associated with OVC, but controversial results have been found. ${ }^{27-29}$

The pathogenesis of these verrucous lesions may be contributed to other factors. The etiology of OVC is complex and strong associations between OVC and alcohol consumption, smoking, areca nut chewing, and oral microbiota have been found. In addition, OVC also shows an association with poor prosthesis, earlier injuries and chronic inflammation, or may result from worsening of premalignant lesions such as oral verrucous leukoplakia. ${ }^{3}$ Previously, a subset of OVH has been shown to be associated with a long duration of tobacco and lime quid placement in the buccal vestibule. ${ }^{30}$

Numerous studies investigated HPV and EBV infections using PCR method, a laboratory technique used to synthesize the multiple copies of a fragment of DNA. This technique is widely accepted due to its more sensitivity and reliability. It has been proposed that in comparison to DNA isolated from fresh or frozen tissue, the quality of DNA extracted from formalin-fixed paraffin-embedded (FFPE) was inferior and may lead to the negative PCR result. ${ }^{31}$ Nonetheless, our study found no HPV and EBV DNA in both OVC and OVH; DNA amplification for GAPDH, a housekeeping gene, was successful in all cases. This indicated that DNA of our samples were good quality for DNA amplification.

\section{Conclusion}

In conclusion, our results do not support HPV and EBV as a potential cause for the development of OVH and OVC in Thai patients. Therefore, further studies may be needed to elucidate the etiology of these lesions.

\section{Funding}

This research was partially supported by International Dental Collaboration of The Mekong River Region (IDCMR) scholarship, Faculty of Dentistry, Mahidol University.

\section{Conflict of Interest}

None declared.

\section{References}

1 Walvekar RR, Chaukar DA, Deshpande MS, et al. Verrucous carcinoma of the oral cavity: A clinical and pathological study of 101 cases. Oral Oncol 2009;45(01):47-51

2 Rekha KP, Angadi PV. Verrucous carcinoma of the oral cavity: a clinico-pathologic appraisal of 133 cases in Indians. Oral Maxillofac Surg 2010;14(04):211-218

3 Peng Q Wang Y, Quan H, Li Y, Tang Z. Oral verrucous carcinoma: from multifactorial etiology to diverse treatment regimens (Review). Int J Oncol 2016;49(01):59-73

4 Noble-Topham SE, Fliss DM, Hartwick RW, et al. Detection and typing of human papillomavirus in verrucous carcinoma of the oral cavity using the polymerase chain reaction. Arch Otolaryngol Head Neck Surg 1993;119(12):1299-1304
5 Fujita S, Senba M, Kumatori A, Hayashi T, Ikeda T, Toriyama K. Human papillomavirus infection in oral verrucous carcinoma: genotyping analysis and inverse correlation with p53 expression. Pathobiology 2008;75(04):257-264

6 de Spíndula-Filho JV, da Cruz AD, Oton-Leite AF, et al. Oral squamous cell carcinoma versus oral verrucous carcinoma: an approach to cellular proliferation and negative relation to human papillomavirus (HPV). Tumour Biol 2011;32(02): 409-416

7 Lin HP, Wang YP, Chiang CP. Expression of p53, MDM2, p21, heat shock protein 70, and HPV 16/18 E6 proteins in oral verrucous carcinoma and oral verrucous hyperplasia. Head Neck 2011;33 (03):334-340

8 Shannon-Lowe C, Rickinson A. The global landscape of EBVassociated tumors. Front Oncol 2019;9:713

9 Wilson JB, Weinberg W, Johnson R, Yuspa S, Levine AJ. Expression of the BNLF-1 oncogene of Epstein-Barr virus in the skin of transgenic mice induces hyperplasia and aberrant expression of keratin 6. Cell 1990;61(07):1315-1327

10 Jang HS, Cho JO, Yoon CY, Kim HJ, Park JC. Demonstration of Epstein-Barr virus in odontogenic and nonodontogenic tumors by the polymerase chain reaction (PCR). J Oral Pathol Med 2001;30 (10):603-610

11 Bagan JV, Jiménez Y, Murillo J, et al. Epstein-Barr virus in oral proliferative verrucous leukoplakia and squamous cell carcinoma: A preliminary study. Med Oral Patol Oral Cir Bucal 2008;13 (02):E110-E113

12 Zhu LK, Ding YW, Liu W, Zhou YM, Shi LJ, Zhou ZT. A clinicopathological study on verrucous hyperplasia and verrucous carcinoma of the oral mucosa. J Oral Pathol Med 2012;41(02):131-135

13 Alkan A, Bulut E, Gunhan O, Ozden B. Oral verrucous carcinoma: a study of 12 cases. Eur J Dent 2010;4(02):202-207

14 Kasperbauer JL, O'Halloran GL, Espy MJ, Smith TF, Lewis JE. Polymerase chain reaction (PCR) identification of human papillomavirus (HPV) DNA in verrucous carcinoma of the larynx. Laryngoscope 1993;103(4 Pt 1):416-420

15 Shroyer KR, Greer RO Jr. Detection of human papillomavirus DNA by in situ DNA hybridization and polymerase chain reaction in premalignant and malignant oral lesions. Oral Surg Oral Med Oral Pathol 1991;71(06):708-713

16 del Pino M, Bleeker MC, Quint WG, Snijders PJ, Meijer CJ, Steenbergen RD. Comprehensive analysis of human papillomavirus prevalence and the potential role of low-risk types in verrucous carcinoma. Mod Pathol 2012;25(10):1354-1363

17 Mitsuishi T, Ohara K, Kawashima M, Kobayashi S, Kawana S. Prevalence of human papillomavirus DNA sequences in verrucous carcinoma of the lip: genomic and therapeutic approaches. Cancer Lett 2005;222(02):139-143

18 Shroyer KR, Greer RO, Fankhouser CA, McGuirt WF, Marshall R. Detection of human papillomavirus DNA in oral verrucous carcinoma by polymerase chain reaction. Mod Pathol 1993;6(06):669-672

19 Saghravanian N, Ghazvini K, Babakoohi S, Firooz A, Mohtasham N. Low prevalence of high risk genotypes of human papilloma virus in normal oral mucosa, oral leukoplakia and verrucous carcinoma. Acta Odontol Scand 2011;69(06):406-409

20 Stokes A, Guerra E, Bible J, et al. Human papillomavirus detection in dysplastic and malignant oral verrucous lesions. J Clin Pathol 2012;65(03):283-286

21 Sritippho T, Pongsiriwet S, Lertprasertsuke N, Buddhachat K, Sastraruji T, Iamaroon A. p16 - A possible surrogate marker for high-risk human papillomaviruses in oral cancer? Asian Pac J Cancer Prev 2016;17(08):4049-4057

22 Gualco M, Bonin S, Foglia G, et al. Morphologic and biologic studies on ten cases of verrucous carcinoma of the vulva supporting the theory of a discrete clinico-pathologic entity. Int J Gynecol Cancer 2003;13(03):317-324

23 Masih AS, Stoler MH, Farrow GM, Wooldridge TN, Johansson SL. Penile verrucous carcinoma: a clinicopathologic, human 
papillomavirus typing and flow cytometric analysis. Mod Pathol 1992;5(01):48-55

24 Nascimento AF, Granter SR, Cviko A, Yuan L, Hecht JL, Crum CP. Vulvar acanthosis with altered differentiation: a precursor to verrucous carcinoma? Am J Surg Pathol 2004;28(05):638-643

25 Chuanyu S, Ke X, Jie Z, Guowei X, Zujun F, Qiang D. Surgical treatment for 11 cases of penile verrucous carcinoma. Ann Dermatol 2011;23(Suppl 3):S346-S349

26 Horiuchi K, Mishima K, Ichijima K, Sugimura M, Ishida T, Kirita T. Epstein-Barr virus in the proliferative diseases of squamous epithelium in the oral cavity. Oral Surg Oral Med Oral Pathol Oral Radiol Endod 1995;79(01):57-63

27 Shimakage M, Horii K, Tempaku A, Kakudo K, Shirasaka T, Sasagawa T. Association of Epstein-Barr virus with oral cancers. Hum Pathol 2002;33(06):608-614
28 Higa M, Kinjo T, Kamiyama K, Iwamasa T, Hamada T, Iyama K. Epstein-Barr virus (EBV) subtype in EBV related oral squamous cell carcinoma in Okinawa, a subtropical island in southern Japan, compared with Kitakyushu and Kumamoto in mainland Japan. J Clin Pathol 2002;55(06):414-423

29 Iamaroon A, Khemaleelakul U, Pongsiriwet S, Pintong J. Coexpression of p53 and Ki67 and lack of EBV expression in oral squamous cell carcinoma. J Oral Pathol Med 2004;33(01): 30-36

30 Hazarey VK, Ganvir SM, Bodhade AS. Verrucous hyperplasia: a clinico-pathological study. J Oral Maxillofac Pathol 2011;15(02): 187-191

31 Srinivasan M, Sedmak D, Jewell S. Effect of fixatives and tissue processing on the content and integrity of nucleic acids. Am J Pathol 2002;161(06):1961-1971 